\title{
Verb Categories at the Morphosyntactic Charactersin Mao
}

\author{
MathiboAdaphro \\ Subject: Linguistics \\ Country:India \\ Central Institute of Indian Languages, Mysore-570006
}

\begin{abstract}
Mao is one of a Tibeto-Burman language family, spoken mainly in the Senapati district of Manipur, north eastern region of India. The language is a subject, object, verb word-order. The language has not been worked much as far as the knowledge of the present writer goes. The present paper is an attempt to the analysis the verb categories at the morphosyntactic characters in Mao.Preliminary analysis revealed that, verb in Mao provides expression about action, occurrence and existence in the sentences indicating their certainty, probability, and times and so on.Detail analysis will focus on the functioning of verb categories based on the morphosyntactic characterization such as Principal verb, Motion verb, Causative verb, Auxiliary verb etc. Generally, many Tibeto-Burman languages do not have tense but commonly have aspect. The present study will also to trace out the functions of both tense and aspect in Mao. The investigation will attempt to study the expressions of mood which a grammatical distinction in verb form that has a wide range of meanings involves through the speaker's attitude in Mao.
\end{abstract}

Key Words: Verb, Mao, Morphosyntactic, Mood, Tense, Aspect.

\section{Introduction}

Verb in Mao, written as well as colloquial forms is one of the major significant grammatical categories as does in other human languages. At the morphological level, verb denotes various expressions such as about the states, events, actions, process extending mood, tense and aspects with suitable affixes. Through the analysis it is found out that Mao is a flexible language that their word order variations are not rigid. Besides, agreement is absent between subject, verb and their gender. Consider the examples (1) given below:
a. aji tay̆-e
I go -Part
'I am going'
b. pfoy̆ra 1 to - coy̆hı - e he fruit eat-Prog-Part
'He is eating fruit'
c. pfoy̆ -khru-mə i vu -e he/she -Pl -Per come Part 'They are coming'

In some situation, verb can be function independently by neglecting their subject and object without concerning the gender distinction as in the illustration (2) given below.

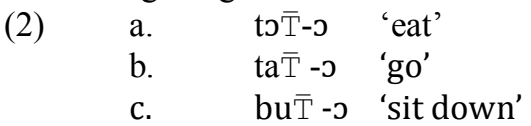

\section{Classification of verb.}

Mao verb may be categorised into fourgroups on the basis of morphosyntactic characterization as (i) Principal Verb, (ii) Motion Verb, (iii) Causative Verb and (iv) Auxiliary Verb.

\subsubsection{PRINCIPAL VERB}

Under the heading of Principal verb, Mao verbs may be sub classified into two as (i) transitive verb and (ii) intransitive verb, depending upon which they can take atleast object or cannot take the object.

(i) Transitive Verb

Transitive verbs should take at least an object when the action takes place. Examples are given below. 
(3)

a.

phi $\overline{\mathrm{T}}-\mathrm{n}$ bo 1 te $-\mathrm{e}$

leg -by ball kick-Part

'(The) ball was kick by foot'

b. $\quad \mathrm{d}$ ni jl-n $\quad \mathrm{l}$ :k ji ka a pi $\quad$-e daniel -Nom lukeAcc money give -Part

'Daniel gave money to Luke'

c. a $-n$ ci ph i k mu hra ji pi -e

I -Nom apple komuharaAcc give -Part

'I gave apple to Komuhra'

(ii) Intransitive Verb

Intransitive verbs cannot take an object when the action takes place. Examples are given below.

(4)
a. mori vu -e
mary come -Part
'Mary is coming'
b. mori -n ni $\quad$-e
mary-Nom laugh -Part
'Mary is laughing'
c. mori $1 \quad \mathrm{~s} \quad-\mathrm{e}$
mary song do -Part
'Mary is singing'

\subsubsection{MOTION VERB}

Motion verbs deal with the activities of either physical or mental. Since all the verbs are in the state of motion; therefore, motion verbs may be divided into (i) process verb and (ii) action verbs. Examples are given below.

(i) Process Verb

(5) a. matheb vu -e

mathebo come - Part

'Mathebo is coming'

b. matheb ta -e

mathebo go -part

'Mathebo is going'

c. matheb ni -e

mathebo laugh - Part

'Mathebo is laughing'

(ii) Action Verb

(6) a. a -n pfoy̆ -jı̆ k pha pi -e

I -Nom she -Acc slap give -part

'I slap her'

b. a -n pfoȳ -jıу day̆ p1 -e

I -Nom he -Acc beat give -Part

'I beat him'

c. a -n pfoy̆ -jıўmoy̆sī̄ p1 -e

I -Nom he -Acckick give -Part

'I kick him'

\subsubsection{CAUSATIVE VERB}


Causative verbs in Mao normally take at least one object. The morpheme may̆ and $m \supset \breve{y}$ are possible to be derived causative from verb as well as an adjective consisting of a single syllable length of word. Examples are given below.

(i) may̆-

$$
\begin{aligned}
& \text { Verb/Adjective } \\
& \text { kray̆ 'cry' } \\
& \text { tay̆ 'go' } \\
& \text { pe 'tell' } \\
& \text { khe 'push' } \\
& \text { day̆ 'beat' } \\
& \text { cīy 'drink' } \\
& 3 \mathrm{e} \text { 'fly' } \\
& \text { dē̄ 'touch' } \\
& \text { krā̄ 'white' } \\
& \text { kī̄ 'dry' } \\
& \text { jī̄ 'good' }
\end{aligned}
$$

(ii)

$$
\begin{aligned}
& \text { mวy̆- } \\
& \text { Verb/Adjective } \\
& \text { to 'eat' } \\
& \text { rì̄ 'write' } \\
& \text { sJ⿳亠丷厂 ' do' } \\
& \text { bu 'sit' } \\
& \text { həy̆ 'red' } \\
& \text { pfoy̆ 'take' } \\
& \text { cэy̆ 'count' } \\
& \text { zoy̆ 'sell' }
\end{aligned}
$$

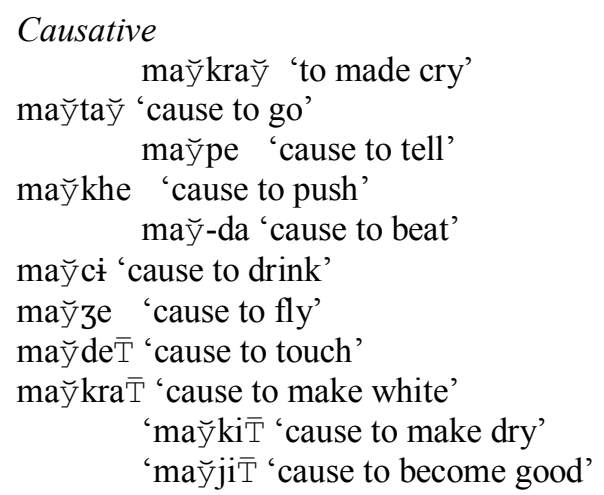

\section{Causative}

mэy̆ts 'cause to eat' mכy̆rīi 'cause to write'

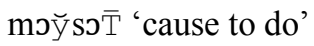

məy̆bu 'cause to sit' moho 'cause to become red'

mopfo 'cause to take'

moco 'cause to count' mozo 'cause to sell'

In Mao, causative verbs normally take at least one agent and one or more object(s). In a sentence at the syntactic point of view, the causative verb denotes the relationship between the causer and the causee. Causative verb may be sub categorised into various ways depending upon the availability of an object(s). They are (i) Mono-transitive causative verb and (ii) Di-transitive causative verb.

(i) Mono-Transitive Causative Verb

This mono-transitive causative verb always take a single object as in example (9) given below.
a. ma ta 'cause to go'
a-n məri ji ma -ta $-\mathrm{e}$
I -Nom maryAccCaus -go -Prog
'I made Mary to go'
b. ma pe 'cause to drink'
a-n mori ji maci -we
I -Nom maryAccCaus -Prog
'I made Mary to drink'
c. $m$ t 'cause to eat'
a-n məri jiy̆ $m$-to -we
I -Nom maryAccCaus -eat -Progending (Aspc)
'I made Mary to eat'

(ii) Di-transitive causative verbs

Di-transitive causative verb is not different from the way of mono-transitive causative verb function, but the di-transitive causative verb take always two objects. Examples are given below.

(10) a. maci 'cause to drink'

a-n məri -ji dzi ma -ci -we

I -Nom Mary -Acc water Caus-drink -Prog ending (Aspc)

'I made Mary to drink water'

b. $m$ t 'cause to eat' 
a-n məri - ji zi $\quad$-phe $n$ ca $m \quad-\quad$-e

I -Nommary-Acc bed -Loc teacaus-drink -Perf

'I made Mary to drink tea on the bed'

c. m hri 'cause to buy'

a-n məri - pe no эca m -sJ⿳亠丷厂 -we
I -Nom mary-Acc tea Caus-do -Prog
'I made Mary to make tea'

\subsubsection{AUXILIARY VERBS}

No lexical elements that function as auxiliary verbs found in Mao. However, there are some composite words such as (i) $\mathrm{m}$ li $\mathrm{i}$ e 'have to', (ii) 1 si 'can', (iii) pra hray̆ 'can't', (iv) pha 'should', (v) pha $\mathrm{m}$ 'should not' and (vi) $\mathrm{m} \quad 1$ 'may' etc., functions the task of an auxiliary verb and express the information about the means of the speaker's attitude of either affirmative or negative. Examples are given below to meet the present work analysis.

(i) $m$ li $i$ e 'have to'
a.
$\mathrm{s} \mathrm{m}$ li i e 'have to do'
ai $v$ s $m$ li $\mathrm{i}$ e
I work do Aux
'I have to do work'
b. ta $m$ li i e 'have to go'
ai $\mathrm{v}$ le ta $\mathrm{m}$ li $\mathrm{i} \mathrm{e}$
I duty to go Aux
'I have to go to duty (office)'
c. pe m li i e 'have to do'
ai cu pe $m$ li i e
I speech tell Aux
'I have to give speech'

(ii) $\quad l \quad s \dot{i}$ 'can'

(12) b. $\quad$ s $\quad 1 \quad$ si

$$
\begin{aligned}
& \text { ai } \quad \mathrm{v} \quad \mathrm{s} \quad \mathrm{si} \\
& \text { I work do Aux -Part } \\
& \text { 'I can do work' }
\end{aligned}
$$

b. ta 1 si
ai ta 1 si - e can walk'
I walk Aux - Part'
'I can walk' (although my leg is in pain)
c. ji 1 si $\quad$ 'can win'
ai $\begin{array}{llll}\mathrm{ji} & 1 & \text { si } & -\mathrm{e}\end{array}$
I win Aux -Part
'I can win' (in the race competition)

(iii) pra hra'can't'

(13) a. ta pra hra 'can't walk'

ai ta pra hra

I walk Aux

'I can't walk' (because my leg is in pain)

b. khe pra hra 'can't push'

ai khee pra hra

I push Aux

'I can't push' (I have no enough strenght)

c. niT̄pra hra 'can't catch' 
ai ni $\bar{T} \quad$ pra hra

'I can't catch' (because the fish is very active and it has a slippery body)

(iv) pha 'should'

$\begin{array}{llllll}\text { (14) a. } & \mathrm{k} & \mathrm{s} & \text { pha } & & \text { 'should do' } \\ & \text { ne } & \mathrm{v} & \mathrm{k} & \mathrm{s} & \text { pha }\end{array}$

you work do Aux

'You have to do work' (as you ate food and drank tea)

b. kata pha 'should go'

ne ka -ta pha

you to -go Aux

'You should go' (to school regularly)

c. ka pe pha 'should speak/tell'

ne ka pe pha

you tell Aux

'You should tell' (to the student to be obedient and study well)

(v) pha $m$ 'should not'

(15) a. $m$ hi pha $m$ 'shouldn't be lazy'

ne $\mathrm{m}$ hi pha $\mathrm{m}$

you lazy Aux

'You shouldn't be lazy' (in doing work)

b. $\mathrm{k}$ t pha $\mathrm{m}$ 'shouldn't eat'

ne khe $\mathrm{t} k \mathrm{t}$ pha $\mathrm{m}$

you rice eat Aux

'You shoudn't eat food' (because you are not working)

(vi) $\quad m \quad l \quad$ 'may'

(16) a. $\quad \mathrm{vu}$-a $\mathrm{m} \quad 1$ 'may come'

pfoy̆i zh vu $-\mathrm{a}$ m 1

he today come-Part Aux

'He may come (home) today'

b. b - a m 1 'may cook'

pfoy̆-nэy̆okhı b -a m 1

he-Nom curry cook-PartAux

'He may cook curry'

c. vo $\mathrm{m}$ a $\mathrm{m} \quad 1 \quad$ 'may not come'

pfoy̆ ido vo $-\mathrm{m} \quad$-a $\quad \mathrm{m} \quad 1$

he tomorrow come-Neg-PartAux

'Tomorrow he may not come'

From the above explanations as well as illustrations (11 to 16) showed that auxiliary verbs normally occur after the main verb. They function as modal verbs and provide the information about obligatory, possibility, necessity, and inability.

\section{TENSE}

Tense a category of the verb which can be normally understood as providing information about the notion of time sequence. The notion of succession points of time, they occupying a fix position of the linear order by either preceding or following other discrete points in the sequence. Tense and aspect are however, difficult to separate from each other as both have the relation with notion of time. (David E Watters) in his Book "A Grammar of Kham" stated that tense and aspect are verb categories that they have a certain value in one category often necessitates the presence of a certain feature in another category, the categories themselves have, 
for reasons of logic, traditionally been kept separate (2004: Pg-257). The fact is that, tense is an inflected forms in the conjugation of verb that give indication of a particular time, past, present and future; also the continuance(imperfective) or completion (perfective) and so on in English, for example:

I am eating food (Prsnt)

I ate food (Pst)

I will eat food (Fut)

I will be eating food (cont)

I had food (Cmpl)

Mao is one of a non-tense language as there is no any marker that is in fix position to denote a particular time.

\section{Aspect}

The concept of aspect is generally understood as a category of verb referring primarily to the way grammar marks the duration or type of activities refers by the verb. In the analysis of aspect, more emphasis is rendered on the indication of duration and types of action of the verb involved rather than the location in time and form the semantic space of aspect, intimately bound up with an indication of tense form which aspect could be differentiated. Comrie (1976. Pg:3) defined as 'aspects are different ways of viewing the internal temporal constituency of a situation'.

However, both aspect and tense are concerned with time in every different ways. Tense for instance, is a deictic category that locates the situation in time usually with reference to the present moment of speaking. Kapfo, K. (2005) specified the tense that "The concept of succession of points of time each one occupying a fix position of the linear order either proceeding or following other discreet points in the sequence. The definition of "tense", however, is controversial and is often difficult to demarcate explicitly from the domain of aspect since both have relation with notion of time (Page 165)".

Aspect, on the other hand concerned much with the completion, duration, repetition, prediction. Thus, aspect views the internal temporal constituency of a situation. The term situation used here is general coverterm, i.e. it may be a state, an event, or a process.

Tenseless languages, generally do not have grammaticalized time reference, though probably all languages can be lexicalised time reference i.e have temporal adverbials that locate situations in time (Comrie 1976). For example, today, tomorrow, yesterday etc. have temporal adverbials that draw a situation in time. But in the treatments of aspect such equality of terminology is not there. The term aspect is to refer to the general semantic oppositions possible. It is to be mentioning that even aspect is a grammatical category just the same as any other grammatical category that may be express by means of an inflectional morphology of the aspectual languages.

Despite earlier linguist, grammarians and other scholars of Mao claimed that this language has tenses. Mentioned may be made that the Scholar like P.P.Giridhar (1994) opined that there are three tenses in Mao, i.e. present, past and future. But those markers assumed as tense are not grammatically distinguished in Mao. It is therefore, nothing but aspect and modality suffixes. Aspect and modality markers are possible to suffix after the verb root at a time but tense cannot do.

The complexity between tense and aspect markers can be illustrate by the following example (17) from the synthetic and analytical point of view.

(17) a. aii do ra i t $\mathrm{t}$-e

I yesterday fruit eat -Aspc

'I ate fruit yesterday'

b. aii $\mathrm{zh}$ ra i $\mathrm{t}$-e

I today fruit eat -Aspc

'I ate fruit today'

c. aii cu ra $\mathrm{i} t$-e

I now fruit eat -Aspc

'I ate fruit now' (just a few seconds of minutes passed)

d. a1 ido ra $\mathrm{i}$ t $\quad$-le

I tomorrow fruit eat - Aspc

'I will eat fruit tomorrow' (after my dinner) 
The above examples (17.a-d) shows that the action or event of the verbs are lies in different times such as $i$ do 'yesterday', $i$ zh 'today'refers the past time, $i \mathrm{cu}$ 'now' refers present time and ido 'tomorrow' refers future time. Hence, different times adverbial denote different time references.

In this present study of aspect, work need to refer the differences between the states or a process or an event. (comrie 1976) stated that 'aspects are different ways of viewing the internal temporal constituency of a situation' (Pg: 3). Mao aspectual has a two basic modal distinction between realis (Re) which refers to situations that have actually taken place or are actually taking place, and irrealis (Ir) which is used for more theoretical situation, including the situation that represent inductive generalizations and also including predication about future.

In Mao, the realis -te and irrealis suffix $-l b$, -we, $-s e$ etc. occurs after the suffixed verb. The above mentioned suffixes however, can be expanded by the morphemes to indicate several aspectual categories.

\subsection{Realis}

Realis takes a modal particle -te in Mao, which involves that the action or event has been realized. Some illustrations are given below in (18. a-c) to show that the time axis is now, and the speaker claims the termination of the habit at some time prior to that time axis.

(18) a ma izhi i ve -pu m -

I Perbelonging steal -repeat Neg -Re

"I do not steal anymore"

b. a1 to -lo -te

I eat -had -Re

'I ate' ( food in the morning)

pfo ta - te

he/she go -Re

'He/she has gone' (to mysore)

\subsection{Irrealis}

Irrelis form indicates the situations (i.e. state, event, or process itself) is the ongoing situation which is yet to reached the concluding point. It is therefore, the state or event is either in the medial space or in the indefinite location in time axis. Irrealis in Mao may be divided into (a) progressive and (b) habitual.

Progressive Irrealis Aspect

Progressive irrealis aspect usually expresses the attitude of the speaker regarding the progressive situation. Examples are given below.
a.

$$
\begin{aligned}
& \text { I tea drink-Prog (Ir) } \\
& \text { 'I am drinking tea' }
\end{aligned}
$$$$
\text { a1 эca эy̆ -we }
$$
b. al la rī̄̄phroy̆ -coy̆ hı e
I paper read Prog (Ir)
'I am reading book.'
c. a1 khıy̆bo -le tay̆ -e
I kohima -Loc go -Prog (Ir)
'I am going to kohima'

In the above example (19. a-c) make it clear to understand progressive irrealis as to indicate states or events are in time axis and it is not known when and what time it has to be finished or end. Progressive irrealis aspect is again may be sub categorise into (i) future progressive and (ii) non-future progressive.

(i) Future progressive

Future progressive irrealis aspect takes the morphemes -le, etc. to combine with the verb root that denoting an action or event is in process and is confirmed. Examples are given below.
(20)
a.
a1 ne vu $k \quad m$ sa khe to to -co - le
I you come till rice eat -Prog-Fut( Ir)
'I will be eating food until you come' 
b. a1 ne jiy̆ ido khuT̄a co -le

I you to tomorrow wait Prog-Fut( Ir)

'I will be waiting for you tomorrow'

c. a1 ne koy̆vo kotosto pro p1 co -le

I you come till cattle grass give Prog-Fut(Ir)

'I will be giving grasses to cattle till you come'

In some situation the perfective markers -te may also use as progressive markers whenever applicable. It bears the meaning of the action being resumed and how long it would have to be continued may not know. Illustrations are given below for the analysis.

(21) a. oci ri -kri vu -tẹ

rain -again come -Aspc

'Rain comes again' (don’t know how long it will rain)

b. ci khrəmohri -kri -vu -țe

wind blow -again -come-Aspc

'The wind (started to) blows again' (since from last night)

c. ko tuy̆ray̆hu khəy̆ vu -țe

cokcoo bird return come - Aspc

'Cokcoo bird comes (back) again' (I heard its singing sound this

morning)

(ii) Non-future progressive

Non-future progressive irrealis aspect cases also in the same manner as future progressive irrealis aspect. It is expressed by the combination of morphemes $-h i e$, -we etc. in example (22) show the denoting action or is in the process and it needs to be continue for some more time. Examples are given below.

(22) a. pfo khe to to - co -hi e

he rice eat-Prog-Aspc

'He is (still) eating rice'

b. oto oproto - co -hi e

cattle grass eat -Prog- Aspc

'Cattle is (still) grazing'

c. pfo 1y̆cū̄ozhe -we

he now sleep -Prog- Aspc

'Now he is sleeping'

d. pfoy̆ -nэıўcū̄ocū̄pe -we

he-Nom now word tell -Prog- Aspc

'Now he is giving speech'

(b) Habitual Irrealis Aspect

Habitual irrealis aspect do not indicate interval of time of any situation, event or process. However, as any situation that can be protracted sufficiently in time or that can be repeated sufficient number times over a long enough period and this means, in effect, almost any situation can be expressed as a habitual. It protracted follows that habituality is in principle combination with various other semantic aspectual values, namely those appropriate to the kind of situation that is protract or repeated. Moreover, the verbal act signifies the aspect. Hence, the marker -we, combines with the verb root in (23) indicates the habitual aspect.

(23) a. $\quad$ o i -noy̆ci kothuni de -we

dogNom everyday bark -Hab (Aspc)

'Dog barks everyday' (not a single day in rest)

b. oto -nэy̆эpro to -we

cattle -Nom grass eat -Hab (Aspc)

'Cattle (usually) grassing grasses' 


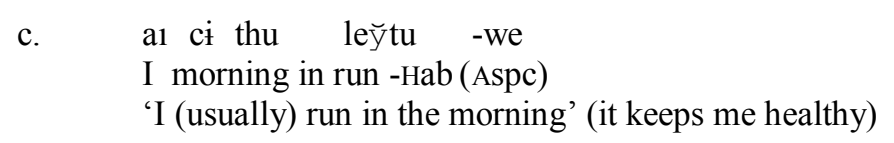

Moreover, the negative marker morpheme -moe in example (24) may also be used as negative habitual aspect marker when the sense of the sentence is naturalized and repeated. Examples are shown below.
(24)
a. oci rimo li odzi dji co -moe
rain without water big do-Neg(Aspc)
'In case there is no rain, there is no flood'
b. ci khrəimohrimo li si ho a lə co -məe
wind blow - if not leaf move do - Neg(Aspc)
'In case there is no wind blow, there is no leaf move/shake'
c. omi de mo li mikhe khe co -moe
fire burn if not smoke(n) smoke (v) do - Neg(Aspc)
'There is no fire, there is no smoke'

\section{Mood}

Mood is denoted by the grammatical distinction in verb form, which expresses a speaker's opinion or attitude to what a person is thinking or telling. The speaker's expression involves a wide range of meaning especially attitudes on the part of the speaker towards the factual content of the person's utterance, i.e. uncertainly, wish, definiteness, possibility, vagueness and so on. Mood in Mao may be classified into four types, such as imperative, optative, Potential and subjunctive.

\subsection{Imperative Mood}

Imperative mood expresses order, request, command or advice in a non-declarative sentence with verifying degree of politeness or of humility. Mao mood markers are employed in various ways and implying different range of meaning. The sentences with imperative markers do not specify addressee or the subject of the sentence; however, it is for the second person is already understood in the semantic contact. Imperative mood markers are used when the speaker willing to convey some information about his attitude or opinion, which are the major concern of discussion in this present paper.

ha $\overline{\mathrm{T}}$ ! implies immediate action without further delay;

lo ! implies gradual activity;

hi $\bar{T}$ da ! implies tentativeness (to act as testing and see the happening result);

$\mathrm{u}$ ! implies order or comment

hī̄ 0 ! implies three meanings as:

(i) that the speaker has no objection to the request,

(ii) that the addressee is delaying action and the speaker orders him for immediate action,

(iii) that the addressor perceive some danger and warn if the addressee dares to do.

iy̌kri! implies the addressee did before and is again requested to do the same. Illustrations are given below.

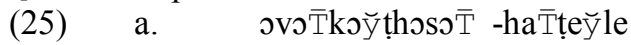

work quickly do -Md will/should

'(The) work should be doing immediately (without further delay)'

b. kəy̆ṭhosō̄ -lo

quick do -Md

'Do it quickly' (so that you will be the first one to finish the work)

c. pfoy̆vō̄koy̆sō̄ he kəy̆ləi -hī̄ da

his work do that look -Md

'(You) watch how he works' (carefully and see the result)

d. $\quad$ ovo $\overline{\mathrm{T}}-\mathrm{t} 1 \mathrm{c} \quad \mathrm{s} \mathrm{\overline { \textrm {T } }}-\mathrm{u}$

work-that do -Md

'Don't do the work' (it is our servant job)

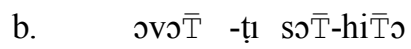

work -that do -Md 
'(You) do the work (i.I have no objection)'

(ii. why delaying?')

(iii. if you dare)'

Imperative mood sentence can also be expressed without a mood marker as in example (26) when the speaker does not show any specific attitude and somewhat impolite form. Examples are given below.

(26) a. he ko

heremd

'Come here' (I will show you my drawing room)

b. ma ra pfovu

sweetmd

'Bring sweet' (we will have in the evening)

c. tay̆ $\mathrm{u} \overline{\mathrm{T}}$

goMd (Neg)

'Don't go' (I want your help in the garden today)

\subsection{Optative Mood}

Optative mood in Mao is marked by a morpheme məy̌s $\overline{\mathrm{T}}$ which imply a wish or desire of the speaker and is usually expressed in the form of imperative mood. Examples are given below.

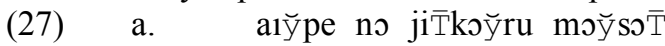

me let win permit Md

'Make me to win' (in the competition)

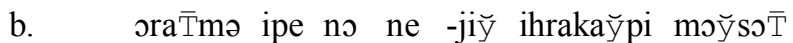

God let you -to bless give Md

'May God bless you?' (to become a good man)

c. pfoy̆kəsokənojī̄koy̆ru məy̆sō

he sickness good permitMd

'May he recover (from) sicknesses (by the grace of God)

\subsection{Potential Mood}

In Mao, the potential mood refers the capability or possibility in the sentence. This potential mood is marked in the sentence by a morpheme ' $l e$ ' implies contingent, should have been and possibility. Examples are given below.

(28) a.

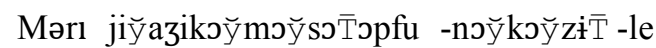

Mary Acc sure father-Nom scold -Md

'It is guaranteed that Mary will get scolding from (her) father'

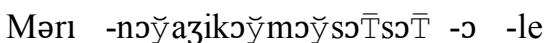

Mary -Nom sure do -can -Md

'Mary's success is guaranteed'

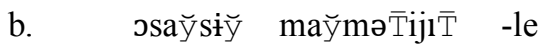

clothDet look good -Md

'(The) cloth may be beautiful (in colour)

la rì̄̄bviy̆siły̆mərı -3ił̌kj -le

bookdet Mary -Poss -Md

'That book may be belong to Mary'

Or

'That book will belong to Mary's'

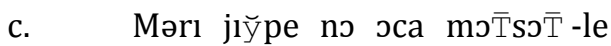

Mary -Acc allow tea caus -Md

'Mary will be ingaged to make tea' 


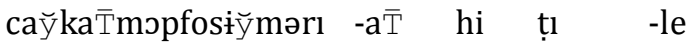
next year Det Mary-event marry possible -Md 'Marry is possible to get marry next year'

\subsection{Subjunctive Mood}

Subjunctive mood refers to the verb form or sentences /clause types in the expression of a contingent or hypothetical action, state or event. This mood in Mao comprises a broad range of meanings, including conditional, tentativeness, purposes and uncertainty etc. In this mood five different morphemes are generally employed in Mao such as:

məy̆țe $\mathrm{a} \overline{\mathrm{T}}$; implies negative conditional

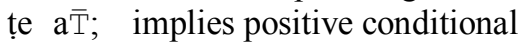

țey̆li ; implies hypothetical tentativeness, and doubts etc.

məy̆lo ; $\quad$ implies in case or lest, with or without condition

duT̄no ; implies purpose

Each of the subjunctive mood illustrations are given in (29) for the purpose of present analysis.

(29) a. moy̆te $a \overline{\mathrm{T}}$

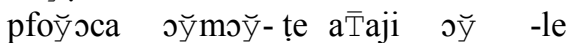

he tea drink Neg-Md I drink -Aspc

'I will drink tea even though if he does not drink'

b. te $a \bar{T}$

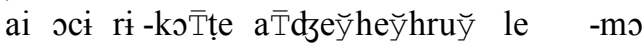

I rain -fall Mdumbrella open Aspc-Neg

'Even if it rain I will not open (use) umbrella'

(lit: Even though rain may come I will not use umbrella)

c. tẹylli

b̄̄̄li ay̆ vu tey̆li ne oca sō̄ -pi - da

lolia come Md you tea do -give-Imp

'You make tea for Lolia when she comes'

d. moy̆ls

ido əci riā̄moy̆lo

tomorrow rain $\mathrm{Md}$

'Tomorrow it may rain (because today is cloudy)'

e. $\quad$ do $\overline{T n}$ o

hri-koro doTno to -we

live -for Md eat -Aspc

'Eating (food) for living'

In the above illustration (29. a-e) show that subjunctive mood in Mao expresses the meanings of uncertainty, tentativeness, purposes and etc.

\section{Conclusion}

It is understood from the above explanation of verb in Mao from the morphological point of view, that it denotes various expressions about states, events, actions, process extending mood, tense and aspects with suitable affixes. It is interesting to know that verb in Mao have severalcategories on the basis of morphosyntactic characterization such as Principal verb which is sub divided into transitive and intransitive verb depending upon which they either can or cannot take the object. Motion verb focuses on the activities of either physical or mental. Ever since, verbs are in the state of motion; thus, motion verbs may be divided into (i) process verb which deal with the action in process and (ii) action verbs which deal that the action do to causee. Causative verb normally take at least one object in Mao. Causative verbs may be sub divided into (i) Monotransitive causative verb involved one object, whereas,(ii) Di-transitive causative verb involved two objects to be a causee. In Mao, usually both intransitive and transitive verbs can be causitivized with the help of causative markers; $/ \mathrm{ma} /$ and $/ \mathrm{mo}$. Auxiliary verb in Mao do not have lexical elements that function as auxiliary verbs. Nevertheless, there are some composite words such as (i) $m$ li $i$ e 'have to', (ii) 1 si 'can', (iii) 
pra hray̆ 'can't', (iv) pha 'should', (v) pha m 'should not' and (vi) m 1 'may' etc., functions the task of auxiliary and convey the information about the means of the speaker either positive or negative.

Tense a category of the verb normally understood as provide the information about the notion of time sequence, they occupying a fix position of the linear order by either preceding or following other discrete points in the sequence. It is mentioned in the explanation above that tense and aspect are however, difficult to separate from each other as both have the relation with notion of time. In the analysis of aspect shows that, more emphasis is rendered on the indication of duration and types of action of the verb involved rather than the location in time. Aspect in Mao has a two basic modal distinction between (i) realis (RE) which refers to situations that have actually taken place or are actually taking place, and (ii) irrealis (IR) which refers the state, event, or process itself is the ongoing situation which is yet to reach the concluding point. Under irrealis aspect there are two categories asprogressive and habitual irrealis aspect.In progressive irrealis aspect there is a categories such as future progressive which takes the morpheme -le and non-future progressive irrealis which has a combination of morphemes $-h i e$, -we to indicate action or is in the process and it needs to be continue for some more time. In some situation the perfective markers -te is use for progressive markers in the situation, whenever, the action that has being resumed and may not know how long it would have to be continue. Habitual irrealis aspect denotes any situation that can be protracted sufficiently in time or that can be repeated sufficient number times over a long enough period and this means, in effect, almost any situation can be expressed as a habitual. It protracted follows that habituality is in principle combination with various other semantic aspectual values, namely those appropriate to the kind of situation that is protract or repeated. Also, the verbal act signifies the aspect by a marker -we combines with the verb root to indicate the habitual aspect. Moreover, the negative marker morpheme -məe is also used as negative habitual aspect marker when the sense of the sentence is naturalized and repeated.

It is understood from the above explanation that, mood is signified by the grammatical distinction in verb form, which expresses a speaker's opinion or attitude to what a person is thinking or telling. The speaker's expression involves a wide range of meaning especially attitudes on the part of the speaker towards the factual content of the person's utterance, i.e. uncertainly, wish, definiteness, possibility, vagueness and so on. Depending upon the attitude of the speaker's, mood in Mao may be classified into imperative which expresses order, request, command or advice in a non-declarative sentence with varying degree of politeness or of humility. Imperative markers in Mao do not specify addressee or the subject of the sentence; however, it is for the second person is already understood in the semantic contact. Optative mood in Mao entail a wish or desire of the speaker and is usually expressed in the form of imperative mood with a marker mっ $\breve{s} \supset \bar{T}$. Maopotential mood refers the capability or possibility in the sentence. Subjunctive mood in Mao comprises a broad range of meanings, including conditional, tentativeness, purposes and uncertainty etc. Mao subjunctive mood may have generally imply five different morphemes such as məy̆țe a $\overline{\mathrm{T}}$ which implies negative conditional, țe a $\overline{\mathrm{T}}$ which implies positive conditional, țey̆li which implies hypothetical tentativeness, and doubts etc., məy̆lo which implies in case or lest, with or without condition and duTno which implies purposes.

\section{NOTES}

(i) Verb in Mao denotes various expressions about states, events, actions, process extending mood, tense and aspects with suitable affixes.

(ii) There are four categories of verbs in Mao such as principal verb, motion verb, causative verb and auxiliary verb.

(iii) Tense generally understood as provide the information about the notion of time sequence, they occupying a fix position of the linear order by either preceding or following other discrete points in the sequence.

(iv) Aspect generally refers the way grammar marks the duration or type of activities refers by the verb. Aspect indicates the duration and types of action of the verb involved rather than the location in time. Mood entails the expression of speaker's opinion or attitude to what a person is thinking or telling.

$\begin{array}{ll}\text { ABBREVIATIONS AND S } \\ \text { Abl } & \text { ablative } \\ \text { Acc } & \text { accusative } \\ \text { Aprox } & \text { approximate } \\ \text { Aspc } & \text { aspect } \\ \text { Aux } & \text { auxiliary } \\ \text { Caus } & \text { causative } \\ \text { Cmpl } & \text { complete } \\ \text { Cont } & \text { continue } \\ \text { Det } & \text { determiner }\end{array}$




$\begin{array}{ll}\text { Fut } & \text { future } \\ \text { Hab } & \text { habitual } \\ \text { Ir } & \text { irrealis } \\ \text { Loc } & \text { locative } \\ \text { Md } & \text { mood } \\ \text { Modf } & \text { modifier } \\ \text { Neg } & \text { negative } \\ \text { Nom } & \text { nominative } \\ \text { Part } & \text { particle } \\ \text { Per } & \text { person } \\ \text { Prog } & \text { progressive } \\ \text { Prsnt } & \text { present } \\ \text { Pst } & \text { past } \\ \text { Re } & \text { realis } \\ \overline{\mathrm{T}} & \text { high tone } \\ & \text { high-mid } \\ & \text { low }\end{array}$

\section{Bibliography}

[1]. Ackerman, F., Goldberg, A. (1996). 'Constraints on Adjectival Past Participles', in A. E. Goldberg (ed.), Conceptual Structure, Discourse and Language, 17-30. Stanford: CSLI.

[2]. Aitchison, J. (1987). Words in the Mind: An Introduction to the Mental Lexicon. Oxford: Blackwell [2002, 3rd revised edition].

[3]. Aitchison, J. (2003). 'Psycholinguistic Perspectives on Language Change', in Joseph and Janda 2003: 736-43.

[4]. Aronoff, M. (1976). Word Formation in Generative Grammar. Cambridge, Mass: MIT Press.

[5]. Aronoff, M. (1994). Morphology by Itself: Stems and Inflectional Classes. Cambridge Mass.: MIT Press.

[6]. Bakker, P. (2003). 'Pidgin Inflectional Morphology and its Implications for Creole Morphology', YoM 2003, 3-35.

[7]. Berko, J. (1958). 'The Child's Learning of English Morphology', Word 14: 150-77

[8]. Blake, B. (1994). Case. Cambridge: Cambridge University Press.

[9]. Blom, C. and Booij, G. E. (2003). 'The Diachrony of Complex Predicates in Dutch: A Case Study in Grammaticalization', ActaLinguisticaHungarica 50:61-91.

[10]. Booij, G. E. (1992). 'Morphology, Semantics, and Argument Structure', in I. Roca (ed.), ThematicStructure: Its Role in Grammar, 47-63. Berlin and New York: Foris.

[11]. Booij, G. E. (2002c). 'Constructional Idioms, Morphology, and the Dutch Lexicon', Journal of Germanic Linguistics 14: 301-27.

[12]. Bosch, P. (1983). Agreement and Anaphora: A Study of the Role of Pronouns in Syntax and Discourse. New York: Academic Press.

[13]. Bybee, J. L. (1985). Morphology: A Study of the Relation between Meaning and Form. Amsterdam: Benjamins.

[14]. Bybee, J. L. (2001). Phonology and Language Use. Cambridge: Cambridge University Press.

[15]. Campbell, L. (2001). 'What's Wrong withGrammaticalization?', Language Sciences 23: 113-61.

[16]. Carstairs, A. (1988). 'Some Implications of Phonologically Conditioned Suppletion', YoM 1988, 67-94.

[17]. Carstairs-McCarthy, A. (1992). Current Morphology. London and New York: Routledge.

[18]. Chomsky, N., and Halle, M. (1968). The Sound Pattern of English. New York: Harper \& Row.

[19]. Chung, S., and Timberlake, A. (1985). 'Tense, Aspect, and Mood', in Shopen1985: 202-58.

[20]. Clark and Berman (2004). 'Morphology in First Language Acquisition', BLM ii, art. 165.

[21]. Clark, H. H. (1979). 'When Nouns Surface as Verbs', Lg 55: 767-811.

[22]. Comrie, B. (1976). Aspect. Cambridge: Cambridge University Press.

[23]. Comrie, B. (1981). Language Universals and Linguistic Typology. Oxford: Blackwell.

[24]. Comrie, B. (1984). Tense. Cambridge: Cambridge University Press.

[25]. Comrie, B. (1985). 'Causative Verb Formation and Other Verb-Deriving Morphology', in Shopen 1985: 309-48.

[26]. Corbett, G. (1991). Gender. Cambridge: Cambridge University Press.

[27]. Corbett, G. (2000). Number. Cambridge: Cambridge University Press.

[28]. Cruse, A. (2000). Meaning in Language: An Introduction to Semantics and Pragmatics, Oxford: Oxford University Press

[29]. David, O. (2005). Introducing Phonology, Cambridge University Press. New York

[30]. Dixon, R. M. W. (1994). Ergativity. Cambridge: Cambridge University Press.

[31]. Elbers, L. (1988). 'New Names for Old Words: Related Aspects of Children's Metaphors and Word Compounds', Journal of Child Language 5: 591-617.

[32]. Fromkin, V. (ed.) (1973). Speech Errors as Linguistic Evidence. The Hague and Paris: Mouton.

[33]. Giridhar, P.P. (1994). Mao Naga Grammar. CIIL, Mysore.

[34]. Greenberg J. (1963). 'Some Universals of Grammar with Particular Reference to the Order of Meaningful Elements', in id. (ed.), Universals of Language, 73-113.Cambridge Mass.: MIT Press. [19662].

[35]. Grimshaw, J. (1990). Argument Structure. Cambridge, Mass.: MIT Press.

[36]. Hammond, M., and Noonan, M. (eds.) (1988). Theoretical Morphology: Approaches in Modern Linguistics. San Diego: Academic Press.

[37]. Haspelmath, M. (1996). 'Word class-Changing Inflection and Morphological Theory', YoM 1995, 43-66.

[38]. Hawkins, J. A. (ed.) (1988). Explaining Language Universals. Oxford: Blackwell.

[39]. Hoeksema, J. (1985). Categorial Morphology. New York: Garland Press.

[40]. Jackendoff, R. S. (1975). 'Semantic and Morphological Regularities in the Lexicon', Lg 51: 639-71.

[41]. Joseph, B.D., and Janda, R.D. (eds.) (2003). The Handbook of Historical Linguistics.Oxford: Blackwell.

[42]. Kapfo, K. (2005). The Ethnology of TheKhezhas And The Khezha Grammar. CIIL, Mysore.

[43]. Kastovsky, D. (1986). 'The Problem of Productivity in Word Formation', Linguistics 24: 585-600. 
[44]. Keller, R. (1994). On Language Change: The Invisible Hand in Language. London: Routledge.

[45]. Koptjevskaja-Tamm, M. (1993). Nominalizations. London and New York: Routledge.

[46]. Kuteva, T. (2002). World Lexicon of Grammaticalization. Cambridge: Cambridge, University Press

[47]. Lappe, S. (2003). 'Monosyllabicity in Prosodic Morphology: the Case of Truncated Personal Names in English', YoM 2002, 35-86.

[48]. Maiden, M. (1992). 'Irregularity as a Determinant of Morphological Change', JL 28: 285-312.

[49]. Marantz, A. (1982). 'Reduplication’ Linguistic Inquiry 13: 83-545.

[50]. Michelle, J.M. (2010). A Phonetic, Phonological, AndMorphosyntactic Analysis of The Mara Language. SJSU Press, San Jose State.

[51]. Nichols, J. (1986). 'Head-Marking and Dependent-Marking Grammar', Lg 62: 56-119.

[52]. Payne, T. E. (1997). Describing Morpho-Syntax: A Guide for Field Linguists. Cambridge: Cambridge University Press.

[53]. Pike, K.L. (1948). Tone Language. Ann Arbor, University of Michigan Press.

[54]. Plag, I. (ed.) (2003a). 'The Morphology of Creole Languages', YoM 2002, 1-134.

[55]. Plag, I. (2003b). Word-Formation in English. Cambridge: Cambridge UniversityPress.

[56]. Riehemann, S. Z. (1998). 'Type-Based Derivational Morphology', Journal of Comparative Germanic Linguistics 2: 49-77.

[57]. Salmon, V. (2000). 'The Term "Morphology", ', BLM i. 15-21.

[58]. Scalise, S. (1984). Generative Morphology. Dordrecht: Foris.

[59]. Selkirk, E. O. (1982). The Syntax of Words. Cambridge, Mass.: MIT Press.

[60]. Song, J. J. (2001). Linguistic Typology: Morphology and Syntax. Harlow: Longman.

[61]. Stump, G. (2001). Inflectional Morphology: A Theory of Paradigm Structure. Cambridge: Cambridge University Press.

[62]. Wiltshire, C., and Marantz, A. (2000). 'Reduplication', BLM i. 557-67.

[63]. Wurzel, W. U. (1980). 'Ways of Morphologizing Phonological Rules', in J. Fisiak(ed.), Historical Morphology, 443-62. The Hague: Mouton.

[64]. Zwicky, A. (eds.) (1998). A Handbook of Morphology. Oxford: Blackwell. 